(RESEARCH ARTICLE)

\title{
Assessment of maize farmers' awareness and effectiveness of indigenous production and preservation practices in Ugbokolo, Benue State, Nigeria
}

\author{
Mary Ojotule Agada, Victor Akwu Otene and Sunday Ogwuche Adikwu \\ Department of Agricultural Extension and Communication, Federal University of Agriculture, PMB 2373, Makurdi, Benue \\ State, Nigeria.
}

Publication history: Received on 15 November 2020; revised on 23 November 2020; accepted on 26 November 2020

Article DOI: https://doi.org/10.30574/wjarr.2020.8.2.0438

\begin{abstract}
This study assessed maize farmers' awareness and effectiveness of indigenous production and preservation in Ugbokolo, Benue State, Nigeria. A sample of 148 maize farmers were selected. Data were collected using a structured questionnaire. Research findings revealed that most farmers were aware of intercropping (92.7\%) and proper drying before storage (95.3\%). The most effective indigenous production practice was early planting $(\bar{x}=2.64)$, while the most effective preservation practice was proper drying before storage $(\bar{x}=2.64)$. The main source of indigenous knowledge was from parents (89.3\%). Based on these findings, it was recommended that other production and preservation practices be introduced to the farmers to broaden their knowledge, and technology for drying of maize be provided to the farmers
\end{abstract}

Keywords: Assessment; Maize Farmers; Awareness; Effectiveness; Indigenous; Production; Preservation

\section{Introduction}

Agriculture is the cornerstone of the Nigerian economy, employing $36.5 \%$ of the entire labour force, and contributing $21 \%$ of the nation's Gross Domestic Product (GDP) [1]. It is the largest economic activity in rural areas where almost $49 \%$ of the population lives [2] and produce about $80 \%$ of the total food, with $33 \%$ of the land under cultivation [3].

Maize (Zea mays L.) has been recognized widely as one of the most potential cereals. Nigeria is the $2^{\text {nd }}$ largest producer of maize in Africa [4], with an annual production of 12.76 million MT in 2018, and is grown over a total land area of about 6.02 million hectares [5]. Maize was rated as the second food crop in Nigeria after cassava [6] and the second main cereal after rice. Maize accounts for $43 \%$ of total calorie intake, and contributes about $7.7 \%$ of total cash income of farm households in Nigeria [7]; [8].

Maize farmers require agricultural information to enhance their production, and the preservation of their harvest [9]. While such information are often introduced to the farmers by agricultural extension agents and other individuals saddled with this responsibility, the indigenous knowledge (IK) possessed by the farmers is very important and should not be ignored for the dissemination of agricultural information to be successful. Over the years, rural farmers depended on IK for maize production and preservation. Such knowledge refers to skills and experience gained through oral tradition and practice over many generations.

[10] Described IK as a systematic body of knowledge acquired by local people through accumulation of experiences, informal experiments, and understanding of their environments. [11] and [12] have established in empirical researches

\footnotetext{
${ }^{*}$ Corresponding author: Mary Ojotule Agada

Department of Agricultural Extension and Communication, Federal University of Agriculture, PMB 2373, Makurdi, Benue State, Nigeria.

Copyright $(2020$ Author(s) retain the copyright of this article. This article is published under the terms of the Creative Commons Attribution Liscense 4.0.
} 
that IK is very important to farmers and the farming community. Appropriately harnessing IK and improved methods of farming will be beneficial. [13] noted that the increasing awareness of the failure of conventional agricultural practices to be effectively equitably applied to the different types of ecologies in which agriculture is practiced has resulted in greater attention being paid to IK.

Ugbokolo in Benue State, Nigeria is recognized for the cultivation of maize. An idea of the indigenous knowledge possessed by the maize farmers in Ugbokolo will be necessary, if it to be enhanced upon and effectively integrated with improved production and preservation practices. This study was therefore designed to determine the farmers' awareness of indigenous maize production and preservation practices, their perceptions of the effectiveness of indigenous production and preservation practices, and the sources of information on indigenous production and preservation practices.

\section{Methodology}

\subsection{The Study Area}

This study was carried out in Ugbokolo, Okpokwu Local Government Area (LGA) of Benue State, Nigeria. The entire LGA is predominantly Idoma Ethnic Nationality. It occupies a landmass of $731 \mathrm{~km}^{2}$, with a population of about 176,647 inhabitants (National Population Commission [14]. The Local Government is located about one hundred and seventy kilometres South-west of Makurdi, the capital of Benue State. It derives its name from River Okpokwu, with the headquarters at Okpoga and is made up of three main districts and twelve council wards with agriculture, particularly maize cultivation as its main source of livelihood [15].

\subsection{Population and Sample Selection}

Maize farming households formed the population for the study, out of which a sample of 150 households were randomly selected across 5 villages. A random sample of 30 farmers aged 40 years and above was drawn from each village. This older people are believed to be better custodians of indigenous knowledge [16].

\subsection{Method of Data Collection and Analysis}

Data were collected by means of structured questionnaire, administered with the assistance of trained extension agents. For quality control, the field exercise was coordinated and supervised by the researchers. Themes included in the questionnaire were related to awareness of IK in maize, perceptions of effectiveness of IK being practiced and sources of information on IK in maize. Descriptive statistics such as frequency, percentage and mean were used for analysis of all the objectives. Although, 150 questionnaires were administered, only 148 were used for analysis as two were mutilated.

Farmers' awareness of indigenous production and preservation practices in maize was measured by presenting to farmers a list of IK practices and asking them to indicate whether or not they were aware of the practices. Frequency and percentage were then obtained for each practice. Farmers' perceptions of effectiveness of indigenous production and preservation practices in maize were measured on a three-point Likert-type scale of Very Effective (3); Effective (2); and Not Effective (1). The values were summed up to obtain a value of 6.0 which was then divided by 3 to get 2.0 which was regarded as the cut-off point. Any item with a response of equal to or higher than 2.0 was taken as effective while those below 2.0 were regarded as not effective. Sources of information on indigenous production and preservation practices in maize were measured by asking farmers to indicate a 'yes' or 'no' answer from a list of sources of information provided. Frequency and percentage were obtained for each source.

\section{Results and discussion}

\subsection{Farmers' Awareness of Indigenous Production and Preservation Practices in Maize}

Research findings, as presented in Table 1 reveal that most (92.7\%) of the farmers were aware of intercropping of maize with other crops. The farmers were also highly aware of fallowing (92.0\%) and early planting of maize (91.3\%). The preservation practices that the farmers were mostly aware of was proper drying before storage (95.3\%) and sun-drying of maize cobs (88.6\%). Intercropping of maize could be as a result of shortage of farm land prevalent in the area, as farmers try to cultivate all they can on the small farm land available. The farmers were therefore knowledgeable about intercropping and early planting of maize. Farmers in the study area practice rain-fed agriculture and take advantage 
of the early rains to plant their maize. This could be responsible for early planting of maize. [17] also found intercropping to be a common practice among farmers in Asia and Africa.

Proper drying of maize is done to ensure that the harvested maize can be preserved for a longer time, as moisture could lead to post harvest losses. The finding of this study agrees with the works of [18] and [19] that drying maize on the bare ground is the most common practice used by farmers all over Africa. Sun-drying of maize is cheap, and this could be the reason the farmers are highly aware of this preservation practice.

Table 1 Respondents' Awareness of Indigenous Production and Preservation Practices in Maize (n=148)

\begin{tabular}{|c|c|c|c|c|c|}
\hline Production practices & Frequency* & Percentage & Preservation practices & Frequency* & Percentage \\
\hline Fallowing & 138 & 92.0 & Proper drying before storage & 142 & 95.3 \\
\hline Shifting cultivation & 94 & 62.7 & $\begin{array}{l}\text { Sorting and grading before } \\
\text { storage }\end{array}$ & 85 & 57.1 \\
\hline Crop rotation & 76 & 50.7 & $\begin{array}{l}\text { Hang maize cobs from hut } \\
\text { roof }\end{array}$ & 86 & 57.7 \\
\hline $\begin{array}{ll}\text { Growing } & \text { suitable } \\
\text { varieties } & \end{array}$ & 80 & 53.3 & Sun-drying of maize cobs & 132 & 88.6 \\
\hline Maize seed selection & 124 & 82.7 & $\begin{array}{l}\text { Cut and stalk maize near the } \\
\text { home }\end{array}$ & 39 & 26.2 \\
\hline $\begin{array}{l}\text { Intercropping maize } \\
\text { with other crops }\end{array}$ & 139 & 92.7 & $\begin{array}{l}\text { Arrange maize cobs on raised } \\
\text { platform } \\
\text { over fireplace }\end{array}$ & 86 & 57.7 \\
\hline $\begin{array}{l}\text { Planting maize on black } \\
\text { clayey soil }\end{array}$ & 20 & 13.3 & $\begin{array}{l}\text { Smoke maize by hanging } \\
\text { over fire place }\end{array}$ & 116 & 77.9 \\
\hline Mulching & 18 & 12.0 & Storing maize in gourds & 63 & 42.3 \\
\hline Early panting of maize & 137 & 91.3 & Storing maize in sacks & 116 & 77.9 \\
\hline Bush burning & 114 & 76.0 & $\begin{array}{l}\text { Storing maize in earthen } \\
\text { pots }\end{array}$ & 44 & 29.5 \\
\hline $\begin{array}{l}\text { Use of organic manure } \\
\text { (poultry droppings, cow } \\
\text { dungs, compost) }\end{array}$ & 49 & 32.7 & Use of solid wall bins & 10 & 6.7 \\
\hline \multirow[t]{4}{*}{$\begin{array}{l}\text { Weeding with hand or } \\
\text { hand-hoe for crop } \\
\text { maintenance }\end{array}$} & 84 & 56.0 & $\begin{array}{l}\text { Keeping maize cobs and } \\
\text { shelled grains on the floor }\end{array}$ & 53 & 35.6 \\
\hline & & & $\begin{array}{l}\text { Use a mixture of red pepper } \\
\text { for maize storage }\end{array}$ & 69 & 46.3 \\
\hline & & & $\begin{array}{l}\text { Use of neem leave extract for } \\
\text { maize storage }\end{array}$ & 37 & 24.8 \\
\hline & & & $\begin{array}{l}\text { Storing maize in traditional } \\
\text { cribs }\end{array}$ & 46 & 30.9 \\
\hline
\end{tabular}

\subsection{Farmers' Perceptions of Effectiveness of Indigenous Production and Preservation Practices in Maize}

The perceptions of the maize farmers on the effectiveness of indigenous production and preservation practices is presented in Table 2. The farmers identified early planting of maize $(\bar{x}=2.64)$ and maize seed selection $(\bar{x}=2.24)$ as the most effective indigenous production practices. Proper drying before storage $(\bar{x}=2.64)$, sun-drying of maize cobs $(\bar{x}=2.21)$ and smoking of maize by hanging over a fire place $(\bar{x}=2.07)$ were the most effective preservation practices among the farmers. 
Farmers consider early planting of maize as effective, because they have to take advantage of the period of rainfall to cultivate their crops. Maize seed selection, which is usually done using previous harvest is also considered as effective, and also very cheap as seeds were not bought. The finding of this study corroborates that of [20], who reported that the effectiveness of IK in maize in Msinga KwaZulu-Natal Province, South Africa was limited due to losses among young people, climatic conditions and the quality of land available to the community. The preservation practices that the farmers consider effective were relatively cheap, and have been practiced over a long period of time. [21] also reported that farmers' perceptions on effectiveness of IK in maize post-harvest management practices were favourable.

Table 2 Respondents' Perceptions of Effectiveness of Indigenous Production and Preservation Practices in Maize $(\mathrm{n}=148)$

\begin{tabular}{|c|c|c|c|c|c|}
\hline & Mean & $\begin{array}{l}\text { Standard } \\
\text { Deviation }\end{array}$ & Preservation practices & Mean & $\begin{array}{l}\text { Standard } \\
\text { Deviation }\end{array}$ \\
\hline Fallowing & 1.87 & 0.94 & Proper drying before storage & 2.64 & 0.64 \\
\hline Shifting cultivation & 1.86 & 0.94 & $\begin{array}{l}\text { Sorting and grading before } \\
\text { storage }\end{array}$ & 1.68 & 0.86 \\
\hline Crop rotation & 1.61 & 0.88 & Hang maize cobs from hut roof & 1.73 & 0.90 \\
\hline Growing suitable varieties & 1.74 & 0.90 & Sun-drying of maize cobs & 2.21 & 0.80 \\
\hline Maize seed selection & 2.24 & 0.80 & $\begin{array}{l}\text { Cut and stalk maize near the } \\
\text { home }\end{array}$ & 1.14 & 0.47 \\
\hline $\begin{array}{l}\text { Intercropping maize with } \\
\text { other crops }\end{array}$ & 2.07 & 0.70 & $\begin{array}{l}\text { Arrange maize cobs on raised } \\
\text { platform } \\
\text { over fireplace }\end{array}$ & 1.52 & 0.80 \\
\hline $\begin{array}{l}\text { Planting maize on black } \\
\text { clayey soil }\end{array}$ & 1.15 & 0.44 & $\begin{array}{l}\text { Smoke maize by hanging over } \\
\text { fire place }\end{array}$ & 2.07 & 0.88 \\
\hline Mulching & 1.09 & 034 & Storing maize in gourds & 1.17 & 0.50 \\
\hline Early panting of maize & 2.64 & 0.73 & Storing maize in sacks & 1.90 & 0.80 \\
\hline Bush burning & 1.99 & 0.77 & Storing maize in earthen pots & 1.17 & 0.50 \\
\hline $\begin{array}{l}\text { Use of organic manure } \\
\text { (poultry droppings, cow } \\
\text { dungs, compost) }\end{array}$ & 1.21 & 0.56 & Use of solid wall bins & 1.02 & 0.20 \\
\hline \multirow[t]{4}{*}{$\begin{array}{l}\text { Weeding with hand or hand- } \\
\text { hoe for crop maintenance }\end{array}$} & 1.50 & 0.72 & $\begin{array}{l}\text { Keeping maize cobs and shelled } \\
\text { grains on the floor }\end{array}$ & 1.24 & 0.51 \\
\hline & & & $\begin{array}{l}\text { Use a mixture of red pepper for } \\
\text { maize storage }\end{array}$ & 1.36 & 0.70 \\
\hline & & & $\begin{array}{l}\text { Use of neem leave extract for } \\
\text { maize storage }\end{array}$ & 1.15 & 0.48 \\
\hline & & & $\begin{array}{l}\text { Storing maize in traditional } \\
\text { cribs }\end{array}$ & 1.42 & 0.66 \\
\hline
\end{tabular}

\subsection{Sources of Information on Indigenous Production and Preservation in Maize}

Parents $(89.3 \%)$ and relatives (40.7\%) were found to be the major sources of information on indigenous production and preservation practices in maize, as presented in Table 3. Other sources included friends, radio programmes, elders, grandparents, social gathering, own discovery, contacts with other cultures, television programmes, and school (Table 6). The findings of this study agree with those of [22] who established that most farmers learnt about IK through parents, relatives, grandparents, neighbours and friends. [21] also submitted that fellow farmers, relatives and radio were the main sources of information on indigenous and organic knowledge. 
Table 3 Nigerian Smallholder Farmers' Sources of Information on Indigenous Production and Preservation Practices in Maize $(n=148)$

\begin{tabular}{|l|l|l|}
\hline Sources of Information & Frequency* & Percentage \\
\hline Elderly & 26 & 17.3 \\
\hline Parents & 134 & 89.3 \\
\hline Grand parents & 26 & 17.3 \\
\hline Relatives & 61 & 40.7 \\
\hline Friends & 28 & 18.7 \\
\hline Social gathering & 13 & 8.7 \\
\hline Own discoveries & 11 & 7.3 \\
\hline Contacts with other cultures & 14 & 9.3 \\
\hline Radio programmes & 22 & 14.7 \\
\hline Television programmes & 13 & 8.7 \\
\hline \multicolumn{2}{r}{ *Multiple responses recorded } \\
\end{tabular}

\section{Conclusion and recommendations}

This study was carried out to assess the awareness and effectiveness of production and preservation practices among maize farmers in Ugbokolo, Benue State, Nigeria. The farmers had high awareness of intercropping of maize and fallowing, as well as proper drying of maize before storage and sun-drying of maize cobs. The farmers also considered intercropping of maize with other crops and maize seed selection as effective with respect to indigenous production practices, while proper drying and sun-drying of maize cobs were considered as effective preservation practices.

The major sources of information on indigenous knowledge was parents and relatives. Based on the findings of this research, the following recommendations are made:

Introduction of other production and preservation practices to the farmers by agricultural extension agents to broaden their knowledge.

Improved technology for drying of maize should be introduced by extension agents for efficient drying of maize cobs.

The indigenous knowledge of the farmers should be documented so that it is easily transferred to next generations, as parents and relatives will not always be there as sources of information.

\section{Compliance with ethical standards}

\section{Acknowledgments}

The authors appreciate members of the communities where the study took place for their cooperation.

\section{Disclosure of conflict of interest}

The authors declare that there is no conflict of interest.

\section{Authors' contribution}

Agada Mary Ojotule and Adikwu Sunday Ogwuche personally collected for the study, while Victor Akwu Otene analyzed the data presented in this paper. All authors have read and approved the final manuscript.

\section{Statement of informed consent}

Informed consent was obtained from all participants interviewed in the study. 


\section{References}

[1] Food and Agriculture Organization (FAO) 2018. Small Family Farms Country Factsheet. 2 pages. Available online: www.fao.org/family-farming/themes/small-family-farmers. Accessed 23rd September, 2020.

[2] World Bank (2019). Rural Population- Nigeria/ Data. Available online: data. worldbank.org>SP.RUR.TOTL. Accessed $20^{\text {th }}$ July 2020.

[3] Maxwell M. Why Agriculture in Nigeria is Important. The Borgen Project. Available online: borgenproject.org>why agriculture in Nigeria is important. 2020.

[4] Food and Agriculture Organization - FAOSTAT (2018). Available online: http://faostat.org/ faostatgateway/golobrowse/Q/Qc. Accessed 9th September, 2020.

[5] National Agricultural Extension and Research Liaison Services (NAERLS). Agricultural Performance Survey Report of 2018 Wet Season in Nigeria. NAERLS, Ahmadu Bello University Zaria Press. 2018

[6] Food and Agriculture Organization (FAO) (2013). FAOSTAT-Agriculture. Available online: http://www.fao.org. Accessed 21 ${ }^{\text {st }}$ September, 2018.

[7] Nweke F. New Challenges in the Cassava Transformation in Nigeria and Ghana. EPTD Discussion Paper No.118. Environmental and Technology Division. International Food Policy Institute, 2033 K Street, NW. Washington D.C. 2004

[8] Alabi RA and Esobhawan B. Relative Economic Value of Maize-Okra Intercrops in Rainforest Zone, Nigeria. Journal of Central European Agriculture, 2006; 7 (3):433-438.

[9] Abedi $M$ and Khodamoradi S. The Role of Agricultural Extension in Integrating Indigenous Knowledge and Modern Knowledge in Rural Areas. Life Science Journal, 2011; 82:254-258.

[10] Tella RD. Towards Promotion and Dissemination of Indigenous Knowledge: A Case Study of NIRD. The International Information Library Review, 2007; 39: 85-193.

[11] Gurung AB. (2002). Indigenous Knowledge of Storage Pest Management in Nepal. Available at: http://ecollection.library.ethz.ch/eserv/eth:25881/eth-25881-02.pdf> Access 21st September, 2018.

[12] Waithaka M. The Role of Indigenous Knowledge in Sustainable Food Production: A Case Study of Post-harvest Practices in Maize Preservation in Mua Hill Location, Eastern Kenya. A Research Project submitted to Van Hall Larenstein University of Applied Sciences in partial fulfillment of the requirement for the awards of master's degree in master of development specializing in rural development and communication. 2011; 55pp.

[13] Hart T and Mouton J. Indigenous Knowledge and its Relevance: A Case Study in Uganda. African Journal of Indigenous Knowledge Systems, 2015; 4 (1):249-263.

[14] National Population Commission (NPC) 2006. National Population census figure, Abuja, Nigeria.

[15] Okpokwu Local Government Background Information on Okpokwu Local Government, Benue State, Nigeria. 2013.

[16] Abdulsalam-Saghir PB and Banmeke TOA. Enhancing Sustainable Environmental Management through Indigenous Pest and Diseases Control Practices by Ofada Rice Growers in Ogun State, Nigeria. Journal of Agricultural Extension and Rural Development, 2015; 7 (3):80-86.

[17] Sagar M, Tanmoy S and Pradipta B. Potential and Advantages of Maize-Legume Intercropping System, MaizeProduction and Use. Available online: https://www.intechopen.com/books/maize-production-anduse/potential-and-advantages-of-maize-legume-intercropping-system. Accessed 9th October, 2020.

[18] Kaaya AN, Kyamuhangire W and Kyamanywa S. Factors Affecting Aflatoxins Contamination of Harvested Maize in Three Agroecological Zones of Uganda. Journal of Applied Sciences, 2006; 6 (11):2401-2407.

[19] Atukwase A, Kaaya AN and Muyanj C. Factors Associated with Fumonisin Contamination of Maize in Uganda. Journal of Science of Food and Agriculture. 2009; 89 (14):2393-2398.

[20] Nyiraruhimbi A. Indigenous Approaches to Maize Production and Soil Management in Msinga KwaZulu-Natal Province, South Africa. A Research Project Submitted in Fulfillment of Academic Requirement for the Degree of Master of Agriculture in Agriculture Extension and Resource Management, School of Agricultural Earth and Environmental Sciences, University of KwaZulu-Natal, Pietermaritzburg, South Africa. 2012. 
[21] Meludu NT and Adesina JB. Bridging the Gap between Old and New Technologies: Considerations of IK in Maize Management Practices in Nigeria. In: Rahnann G and Aksoy U (Eds.), Proceedings of the $4^{\text {th }}$ Conference 'Building Organic World Conference', 2014; 13-15 October, Istabul, Turkey:pp.851-854.

[22] Lwoga ET, Ngulube P and Stilwell C. Managing Indigenous Knowledge for Sustainable Agricultural Development in Developing Countries: Knowledge Management Approaches in the Social Context. The International Information and Library Review, 2010; 42:174 - 185. 